\title{
Analysis of Mangrove Crab (Scylla sp) Catch Caught by Trap in Different Construction as Operated in Oebelo Village Waters, Central Kupang Sub-district, Kupang Regency
}

\author{
Risamasu, F. J. L. \\ Lecturer Faculty of Agriculture Fisheries and Marine Undana University, Kupang \\ Yahyah \\ Lecturer Faculty of Agriculture Fisheries and Marine Undana University, Kupang \\ I. Tallo \\ Lecturer Faculty of Agriculture Fisheries and Marine Undana University, Kupang \\ Kiik G. Sine \\ Lecturer Faculty of Agriculture Fisheries and Marine Undana University, Kupang
}

Received: February 1, 2014 Accepted: June 3, $2014 \quad$ Published: June 27, 2014

doi:10.5296/jee.v5i1.5877ＵRL: http://dx.doi.org/10.5296/jee.v5i1.5877

\begin{abstract}
This study is conducted in Oebelo waters, Central Kupang Sub-district from October to December, 2013. It aims to find out the fishing power of trap (ID: bubu) in different types toward mangrove crab catch. It uses observation method by experimental fishing for one month. The findings show that the caught crab consists of 6 species, i.e. Scylla serrata, $S$. transquabarica, S. olivacea, Portunus pelagicus, Charybdis granulata and C. anisodon which six of these species are caught in every trap type. The caught crab species with the highest proportion is Scylla serrata by 60 crabs (58.823\%), then followed by the other species. Trap type having the highest abundance rate is conical type code B 2.3, then conical type code B 3.2 and followed by the other types. Trap code B 2.3 and B 3.2 is the trap prototype having the higher fishing power compared to the others. Trap having the highest CPUE value is conical shape type code B 3.2, followed by semicircular shape code C 3.2, cube-shaped type code A 2.2 and the other types. Trap engineering in this observed crab
\end{abstract}


fishing is one of the important information to improve the trap construction design and mangrove crab fishing method by utilizing trap in the future.

Keywords: Trap, Catch, Mangrove crab 


\section{Introduction}

Oebelo belongs to one of coastal villages in the northeast Kupang Bay. Based on the administrative data, it belongs to East Kupang Sub-district, Kupang Regency. Coastal waters in Oebelo village is grown by mangrove flat as the living habitat of waters organism such as fishes, shrimps, crabs, etc. Besides having important role as habitat of various biota, mangrove forest also produces fishery biological resources.

The existence of fishery resources in mangrove forest have helped fishing community in Oebelo village in developing fishery business either in fishing activity or aquaculture. Leading fishery activities developed by local community is fishing activity. They catch fishes, shrimps, crabs, and other organism. Fish and biota fishing still uses traditional fishing equipment such as gill net, trap, and even hand-baring to catch the cockle shell (Risamamu, et al, 2011).

One of mangrove forest resources utilized most by Oebelo villagers is mangrove crab (Scylla $\mathrm{sp}$ ). Mangrove crab becomes one of high market value marine biota. In the overseas, price of CB graded mangrove crab may reach US\$8.40-9.70 per $\mathrm{kg}$ while LB graded crab costs US\$6.10-9.00 per kg. For super crab in size of $>1000 \mathrm{~g}$ may cost US\$10.5 per $\mathrm{kg}$. Therefore, soft-shell crab production is quite promising (Karim, 2009). Considering the promising sales value of mangrove crab in the market, those fishermen are interested in catching mangrove crab.

Low-frequency crab catch may caused by traditional fishing gear owned by the fishermen and fisherman's experience-based design in the fishing gear. Therefore, an effort to increase production of mangrove crab catch is a need through technology improvement to the fishing gear design and its fishing method.

Trap had been developed to catch fishes, crabs, and other water organism. The use of trap in fishing or other animals catch has different construction design. Fisherman's knowledge in designing fishing gear, specifically for trap, to catch mangrove crab is too basic for crab's fisherman in Oebelo village. Special feature of trap in catching crabs is that it can catch some crabs in one-catch with living caught crabs which will not reduce its quality and freshness. Considering trap design and its traditional catch method, there should be any other alternatives to increase production of mangrove crab catch by engineering this local trap, diameter size, funnel count and funnel position corresponds to research topic priority in MP3EI on capture fishing strategy. Meanwhile, the aim of this study is to find out the fishing power of trap in different type (cube-shaped, semicircular, and conical shape), funnel's diameter size, count and position toward mangrove crab catch either its species composition, number of crab per species, weight, and crab's abundance.

\section{Research Method}

This study is conducted in Oebelo waters, Central Kupang Sub-district from October to December, 2013. Used equipments in this study consist of trap in different type (cube-shaped, semicircular, and conical shape) with three funnel diameter types ( $\varnothing 14 \mathrm{~cm}, 16 \mathrm{~cm}$, and 18 $\mathrm{cm}$ ), funnel count and position. There are three positions of funnel, i.e one funnel on top, two 
side-funnels and 3 funnels with one funnel on top and 2 side-funnels. Catch supporting equipments are fishing vessel with diesel engine 8.5 HP, GPS to detect the trap placement position in every station, digital scales, caliper, bucket, crab storage box, camera, and stationary to collect the data, while the used material is fish bait (rayfish and shark meat).

\section{Research Procedure}

This study uses observation method through experimental fishing with trap which had been engineered. Data sampling stages are follows:

1) Before placing the trap in research site, firstly, location survey is conducted to the crab catch places surrounding mangrove forest in Oebelo village waters. This location survey aims to determine the appropriate location to place the trap.

2) Surveyed locations are divided into three observed stations. Station 1 is used to operate the cube-shaped trap, station 2 for the conical shape trap, and station 3 for semicircular trap.

3) There are three types of the operated trap, i.e. cube-shaped, semicircular, and conical shape with three funnel diameter sizes $(\varnothing 14 \mathrm{~cm}, 16 \mathrm{~cm}$, and $18 \mathrm{~cm})$, funnel count and position. There are three positions of funnel, i.e 1 funnel on top, 2 side-funnels and 3 funnels with 1 funnel on top and 2 side-funnels. Each of this trap is made 9 units, then total number of the used trap in this study is 27 units.

4) This trap is placed in mangrove forest waters. Catch operation is conducted before high tide comes.

5) Observed variables consist of species composition, number per species, crab weight, and number of fishing per trip.

6) Determination on the caught crab by means of trap is identified by applying Keenan (1999) and Matsuura, et al (2000) instruction.

4. Data Analysis

\subsection{Proportion of the Caught Mangrove Crab Amount}

Proportion of the caught mangrove crab amount is calculated based on the following instruction (Risamasu, 2008):

$$
\text { Proportion }(\mathbf{P})=\frac{\mathrm{ni}}{\mathrm{N}} \times 100 \%
$$

where

$$
\mathrm{P}=\text { Proportion of each fish species }
$$

$\mathrm{ni}=$ Amount of the $i$ th species

$\mathrm{N}=$ The total of all proportion

\subsection{Abundance Analysis of Mangrove Crab}

Abundance analysis of mangrove crab caught by trap is based on Odum (1971) instruction as follows: 
where

$$
\mathrm{X}=\frac{\sum \mathrm{Xi}}{\mathrm{n}}
$$

$\mathrm{Xi}=$ Amount of coral reef fish in the $i$ th observation station

$\mathrm{n}=\quad$ trap type size $\left(\mathrm{m}^{2}\right)$; cube-shaped size: $2.16 \mathrm{~m}^{2}$; conical shape size:

$0.914 \mathrm{~m}^{2}$, semicircular shape size: $0.942 \mathrm{~m}^{2}$

\subsection{CPUE Analysis}

Catch per unit effort (CPUE) analysis of the caught mangrove crab by using trap is gained from the division of total catch and the effort based on the instruction of Gulland (1983) as referred by Gunawan (2004) as follows:

$$
\mathrm{CPUE}=\frac{C i}{f i}
$$

Where $\quad$ CPUE $=$ Amount of the $i$ th catch per unit effort $(\mathrm{kg} /$ trip)

$$
\begin{aligned}
& \mathrm{Ci}=\text { The } i \text { th catch }(\mathrm{kg}) \\
& \mathrm{Fi}=\text { The } i \text { th effort (trip) }
\end{aligned}
$$

\section{Findings and Discussion}

\subsection{Mangrove Crab Species Composition and Amount Caught by Trap}

There were found 6 species composition of mangrove crabs consisting of Scylla serrata, $S$. transquabarica, S. olivacea, Portunus pelagicus, Charybdis ranulate, and C. anisodon. From these six caught species, the largest caught species is Scylla serrata by 60 individual, then followed by Charybdis ranulate by 30 individual, and the others as presented in Table 1.

Table 1. Mangrove Crab Composition and Amount Caught by Every Trap Type

\begin{tabular}{|c|c|c|c|c|c|c|}
\hline \multirow{2}{*}{$\begin{array}{c}\text { Trap } \\
\text { Type }\end{array}$} & \multicolumn{7}{|c|}{ Crab Species } \\
\cline { 2 - 7 } & $\begin{array}{c}\text { Scylla } \\
\text { serrata }\end{array}$ & S. transquebarica & S. olivacea & $\begin{array}{c}\text { Portunus } \\
\text { pelagicus }\end{array}$ & $\begin{array}{c}\text { Charybdis } \\
\text { granulata }\end{array}$ & C. anisodon \\
\hline A1.1 & 3 & - & - & - & - & - \\
\hline A1.2 & - & - & - & - & - & - \\
\hline A1.3 & - & 1 & - & - & - & - \\
\hline A2.1 & - & - & - & - & 2 & - \\
\hline A2.2 & 3 & - & - & - & 2 & - \\
\hline A2.3 & 1 & 1 & - & - & 2 & - \\
\hline A3.1 & 2 & 1 & - & - & 2 & - \\
\hline A3.2 & 2 & - & - & 1 & 1 & - \\
\hline A3.3 & 3 & - & - & 1 & 1 & - \\
\hline B1.1 & - & - & - & - & 1 & - \\
\hline B1.2 & 2 & - & - & - & - & - \\
\hline B1.3 & - & - & 1 & - & - & - \\
\hline
\end{tabular}




\begin{tabular}{|c|c|c|c|c|c|c|}
\hline $\mathrm{B} 2.1$ & 3 & - & - & - & - & - \\
\hline $\mathrm{B} 2.2$ & 4 & 1 & - & - & 2 & - \\
\hline $\mathrm{B} 2.3$ & 7 & - & - & 1 & 2 & - \\
\hline $\mathrm{B} 3.1$ & 2 & - & - & - & 2 & - \\
\hline $\mathrm{B} 3.2$ & 9 & - & - & - & 1 & - \\
\hline $\mathrm{B} 3.3$ & 3 & - & - & - & 2 & - \\
\hline $\mathrm{C} 1.1$ & - & - & - & - & 1 & - \\
\hline $\mathrm{C} 1.2$ & 1 & - & - & - & - & - \\
\hline $\mathrm{C} 1.3$ & 1 & - & - & - & 1 & - \\
\hline $\mathrm{C} 2.1$ & 3 & - & - & - & 4 & - \\
\hline C2.2 & 1 & - & - & - & 1 & - \\
\hline C2.3 & 1 & - & - & - & - & 1 \\
\hline C3.1 & 4 & - & - & - & - & - \\
\hline C3.2 & 2 & 1 & 1 & 1 & 2 & - \\
\hline C3.3 & 3 & - & - & - & 2 & 1 \\
\hline Total & 60 & 5 & 2 & 4 & 30 & 0.98 \\
\hline Proportio & 58.823 & 4.902 & 1.961 & 3.923 & 29.412 & \\
\hline n (\%) & & & & & & \\
\hline
\end{tabular}

Table above shows that among all of the caught crab species by using trap, the most caught species is Scylla serrata by 60 individual (58.823\%), then followed by Charybdis ranulate by 30 individual $(29,412 \%)$ and the other crab species as presented in Figure 1.
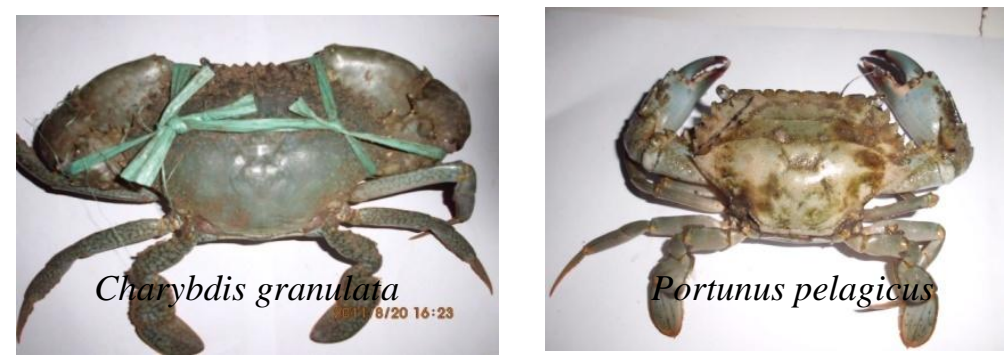

Figure 1. The Mangrove Crab Species Caught by

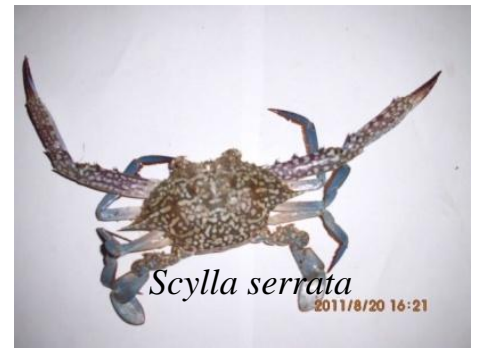

Trap

\subsection{Abundance of Trap Catch}

Abundance of crab catch in every trap type based on the findings is presented in Figure 2. 


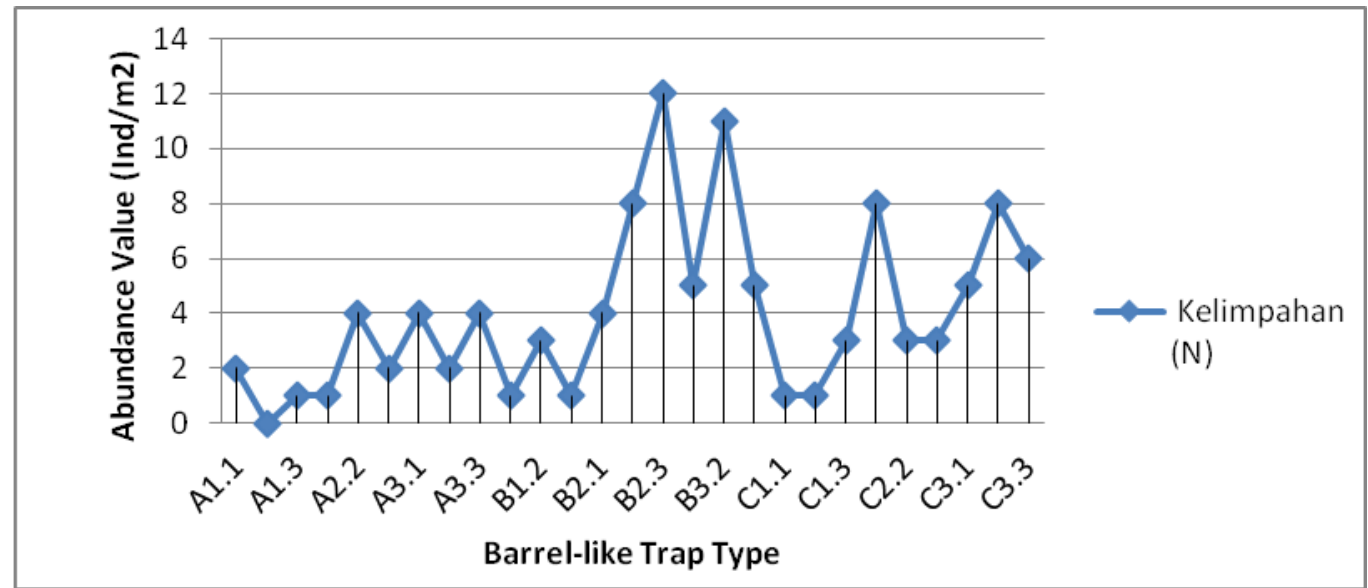

Figure 2. Abundance of Mangrove Crab in Every Trap Type

Figure 2 shows that trap type reaching the highest abundance value is conical shape type code B 2.3 by 12 individual $/ \mathrm{m}^{2}$, then followed by conical shape code B 3.2 by 11 individual $/ \mathrm{m}^{2}$, and trap type code B $2.2, \mathrm{C} 2.1$, and C 3.2 by 8 individual $/ \mathrm{m}^{2}$ respectively and then followed by the other types. However, as a whole, trap having the highest abundance is the conical shape compared to the semicircular and the cube-shaped ones.

An interesting finding in this study is that till the end of the study, the trap type of A 1.2 (cube-shaped trap with 2 side-funnels with funnel diameter $14 \mathrm{~cm}$ ) does not catch any crabs, then its abundance value is zero. It is presumed that the weakness lies on the shape and funnel position with the smaller diameter that made the crab were not trapped. Besides, it may be placed in waters with torrential current, so it affects crab's swimming pattern, especially for crabs with limited swimming capability or crabs which mostly move by crawling.

\subsection{Mangrove Crab Catch Based on Fishing Trip}

Based on the findings, gained amount of mangrove catch in every trap type and shape is presented in Figure 3.

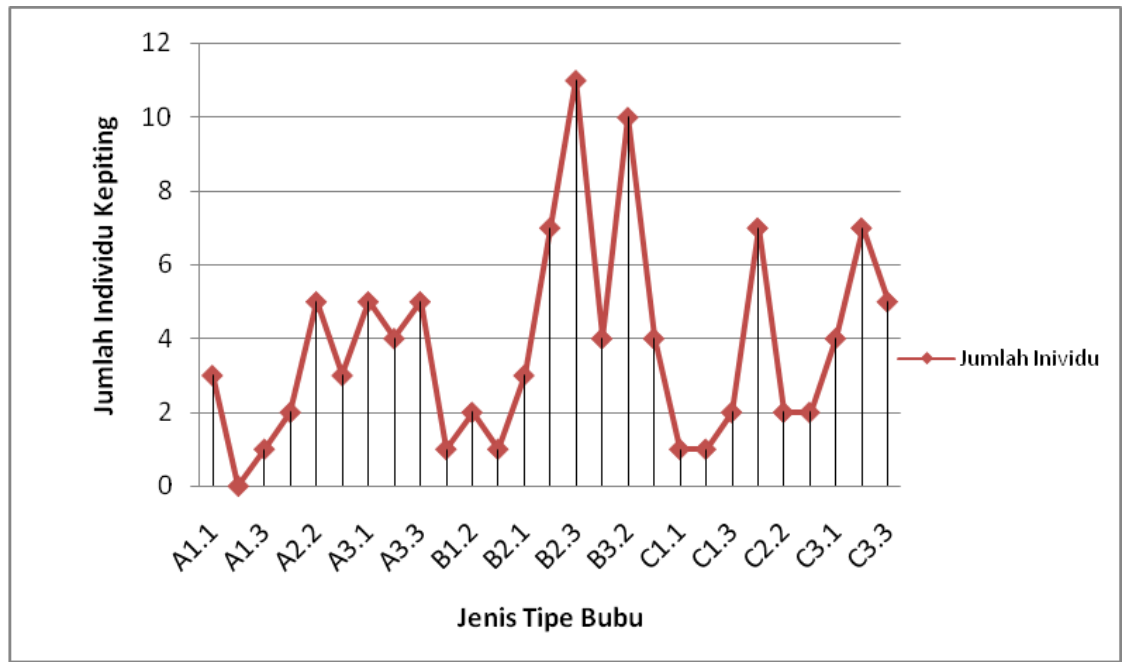

Figure 3. Amount of the Caught Mangrove Crab in every Trap Type 


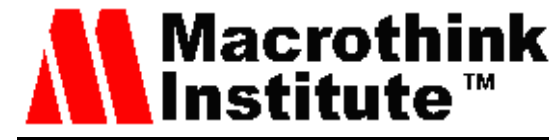

Figure 3 shows that the amount of catch through fishing trip reaches 14 times if it uses conical shape trap (Code B). It reaches the largest catch amount with total catch by 43 individual (42.15\%), followed by semicircular shape (Code C) with the caught amount 31 individual (30.39\%) and cube-shaped type (Code A) with the caught amount 28 individual (27.45\%). In general, this finding indicates that conical trap (Code B) has the better fishing power, followed by semicircular (Code C) and cube-shaped trap (Code A). Furthermore, based on trap type, it seems that the largest catch amount is trap type code B 2.3 (conical trap with funnel diameter $18 \mathrm{~cm}$ and 3 funnels having 1 funnel on top and 2 side-funnels) which catches 11 individuals, followed by trap code B 3.2 (conical trap with funnel diameter $16 \mathrm{~cm}$ and 2 side-funnels) which catches 10 individual. Based on the data, it can be said that conical shape trap (Code B) has the higher fishing power compared to semicircular type (Code C) and cube-shaped type (Code A). However, based on the type, trap type code B 2.3 and B 3.2 is the prototype having the higher fishing power compared to the others.

Total weight of trap catch for all types is $10,075 \mathrm{~g}(10.075 \mathrm{~kg})$. Total weight of the largest catch is by using conical-shaped trap (Code B) by 4,212 $\mathrm{g}(4.212 \mathrm{~kg}$ ) or $41.81 \%$, followed by cube-shaped type (Code A) by 3,257 g (3.257 kg) or 32.33 and semicircular shape (Code C) by $2,606 \mathrm{~g}(2.606 \mathrm{~kg})$ or $25.86 \%$.

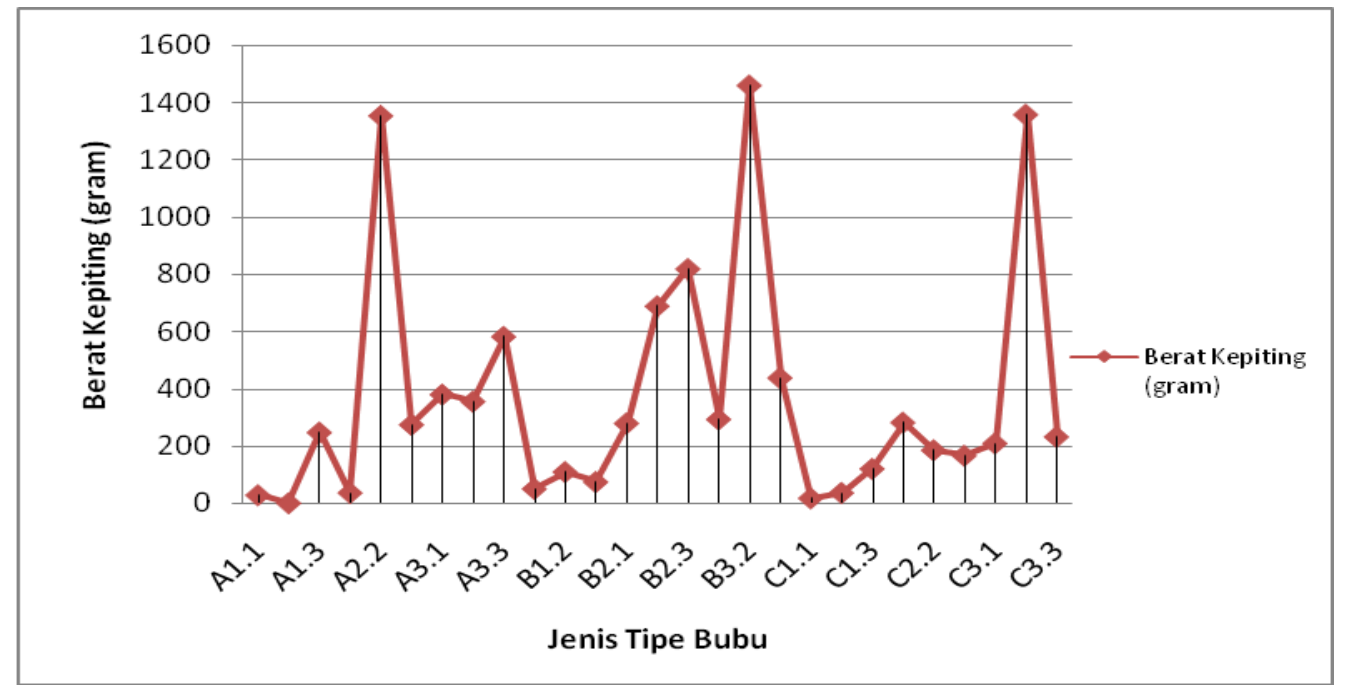

Figure 4. Mangrove Crab Weight in Every Trap Type

The difference of total catch weight is not only based on the amount of caught crabs, but also the crab's size of every crab species. According to Mahonas, et al. (2012) the use of cube-shape trap, conical-shaped trap, and flower shape trap in different construction to catch mangrove crab in 15 times catching found that the largest catch amount is caught by using the cube-shape trap by 40 crabs $(73 \%)$ with total weight of $6,475 \mathrm{~g}(75 \%)$, while the average catch of every setting is 3 crabs with average weight of $161 \mathrm{~g} / \mathrm{crab}$. Furthermore, total catch by using conical-shaped trap is 12 crabs (22\%) with total weight $1,665 \mathrm{~g}(19 \%)$, while total catch by using flower shape trap is 3 crabs $(5 \%)$ with total weight $543 \mathrm{~g}(6 \%)$.

According to Mahonas, et al. (2012), trap type having high fishing power is the cube-shaped 


\section{Macrothink}

trap compared to the conical-shaped and flower shape trap. Yet, based on this finding, indeed, conical-shaped trap has the higher fishing power compared to the cube-shaped and semicircular type. Then, this finding is linked to JICA's (2001) statement by stating that two trap types which is suggested to catch the target species such as crab is cone-shaped trap with funnel position on top where this type's target is tanner crab (crawling crab). While semicircular-shaped trap (collapsible half-ball type) with two side-funnels is used to catch Gazami crab (swimming crab)/small crab. By correlating this finding and JICA's (2001) statement, it is found that the treated conical-shaped trap in this study has high fishing power compared to the others as seen in Figure 5.
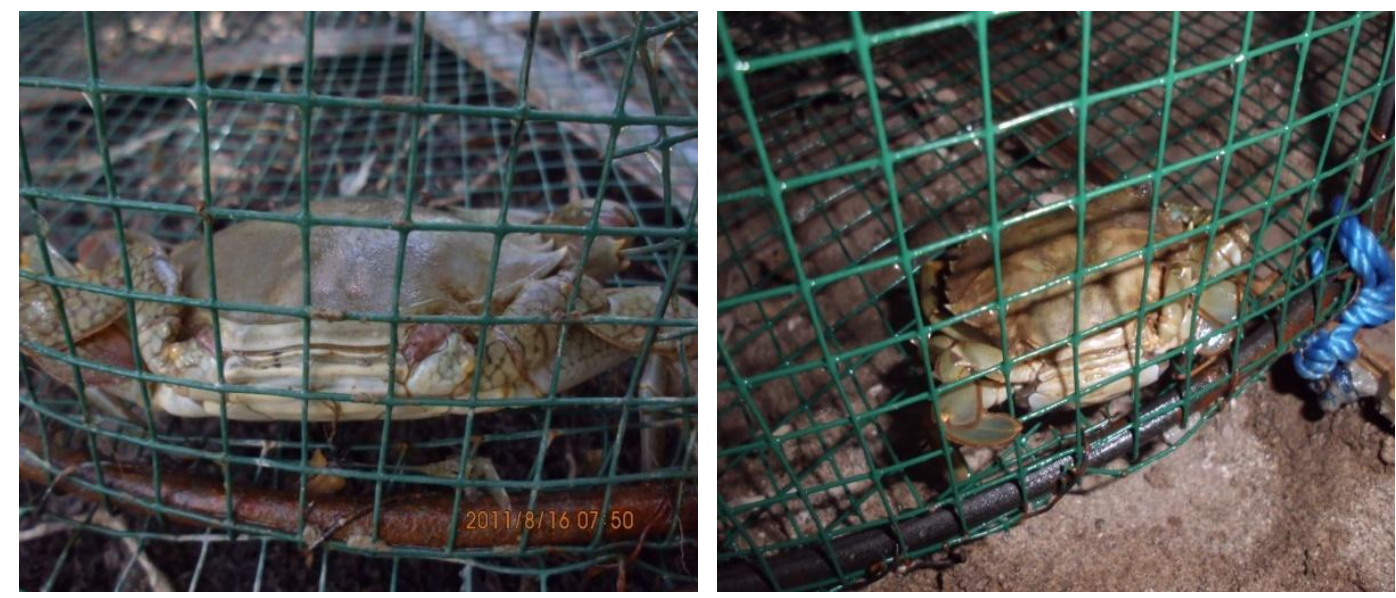

Figure 5. Mangrove crab trapped by the trap

Value of Catch per Unit Effort (CPUE) for all catch by using trap is $0.722 \mathrm{~kg} /$ trip. trap group having the highest CPUE value is the conical-shaped type by total catch $0.302 \mathrm{~kg} / \mathrm{trip}$, followed by the cube-shaped type by $0.233 \mathrm{~kg} /$ trip and semicircular-shaped type by 0.187 $\mathrm{kg} /$ trip. Then, trap type having the highest CPUE is conical shape type code B 3.2 by reaching $0.104 \mathrm{~kg} /$ trip, followed by semicircular type code $\mathrm{C} 3.2$ by $0.097 \mathrm{~kg} /$ trip and cube-shaped type code A 2.2 by $0.096 \mathrm{~kg} /$ trip and followed by the other types (Figure 6). 


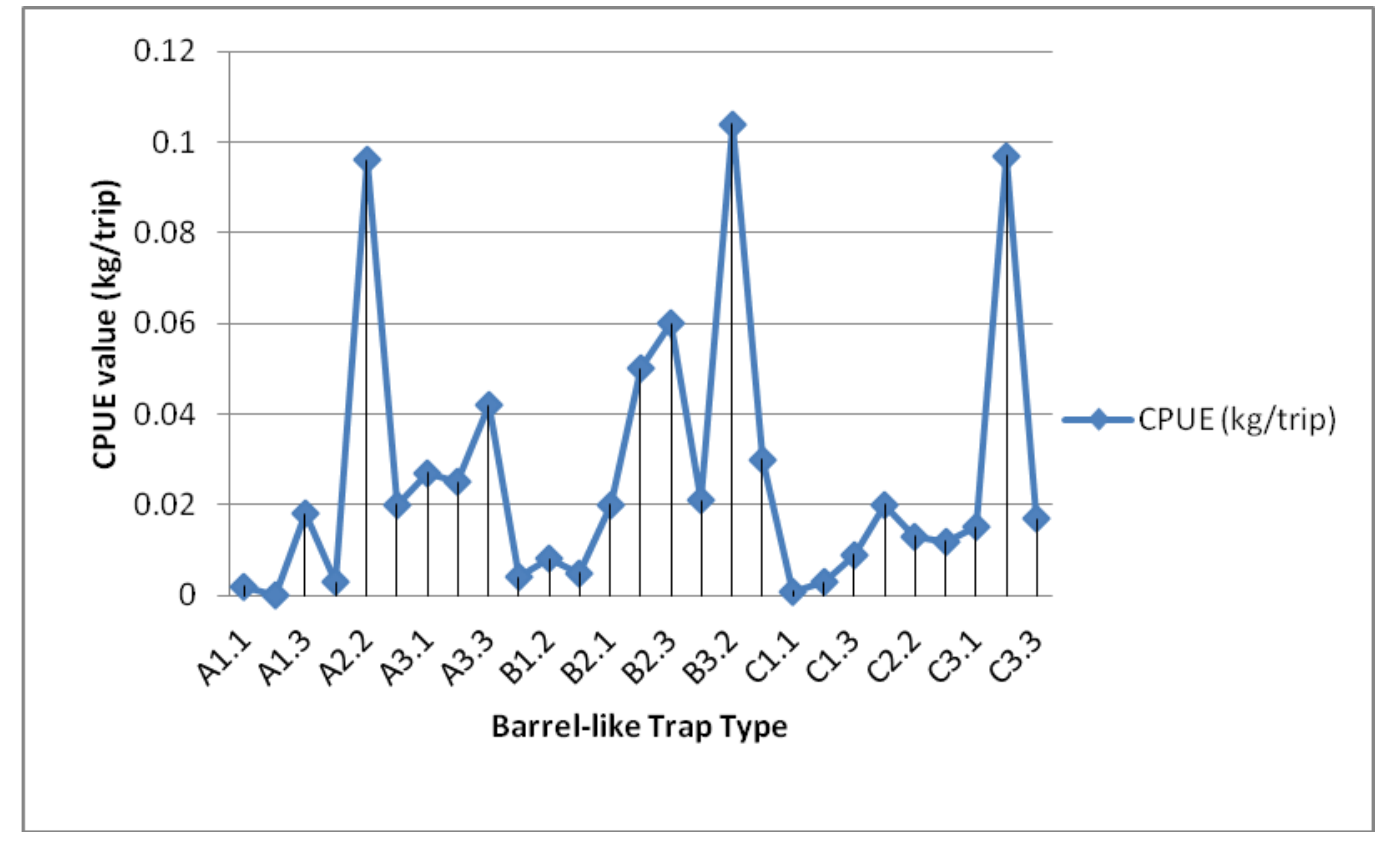

Figure 6. CPUE Value of Mangrove Crab in Every Trap Type

The influence of trap on CPUE value of every trap is highly influenced by size of the every caught crabs. The low rate of mangrove crab catch is not only caused by trap type, but also by fishing area condition. Fishing location used to operate the trap is a location where the area is utilized by fishermen to catch those mangrove crabs as always. Through regular utilization pattern in every chance, indeed, it will affect mangrove crab population decrease in mangrove forest waters. Besides, crab fishing conducted in this study have been counted to seasonal phase when it is not the peak of crab fishing season.

According to local fisherman's information, the peak of mangrove crab fishing season in Oebelo village waters is between August to October. Whereas, this trap operation is conducted in November to the first week of December. Besides, the conducted crab fishing have came into rainy season transition that highly affect the wholeness of fishing activity. On the other side, bad weather condition is highly affect the crab catch process when the rain comes, this catch is stopped.

In this study, the used fish bait is rayfish from species Himantura ndulate and Taeniura lymna in family Dasyatidae, and also shark meat. The use of rayfish as the fish bait gives the better response toward the crab catch compared to shark meat.

According to Muchlisin and Azwir (2004), the used fish bait with chopped chicken-head fish bait is more effective to increase the crab catch by 35 crabs, followed by the use of cow hide that catch 26 crabs, 24 crabs by crab meat, 18 crabs by trash fish, and 13 crabs by coconut cake.

\section{Conclusion}

Based on the obtained data, it can be concluded as follows: 
1) The caught mangrove crab species in every type of trap in a whole consists of 6 species, i.e. Scylla serrata, S. transquabarica, S. olivacea, Portunus pelagicus, Charybdis granulata and $C$. anisodon, while the largest proportion of caught mangrove species is Scylla serrata and then followed by other species.

2) trap type having the highest abundance rate is conical shape code B 2.3, followed by conical shape code B 3.2 and the other types.

3) trap code B 2.3 and B 3.2 is prototype fishing gear having great fishing power as seen from the total catch amount which is higher than the others.

4) The highest total weight of mangrove crab catch is by using conical shape trap and then followed by the other two trap types.

5) trap type having the highest CPUE rate is the conical shape trap code B 3.2, followed by semicircular shape code C 3.2, and the cube-shaped trap code A 2.2 and the other types.

\section{Suggestion}

Based on this findings, it is suggested to conduct advance study on the influence of water quality on mangrove crab catch. Besides, there should be a study on the influence of fishing time on crab catch.

\section{References}

Gunawan, A. (2004). Analisis pola musim penangkapan dan pemanfaatan ikan Teri di Kabupaten Tuban, Jawa Timur [skripsi]. Bogor: Program Studi Pemanfaatan Sumberdaya Perairan, Fakultas Perikanan dan Ilmu Kelautan, Institut pertanian Bogor.

JICA. (2001). Net Fishing (Pot Fisheries) Fishing technology. Textbook Vol.8. Regional Fisheries Training Project, Japan International Cooperation Agency (JICA), Caribbean Fisheries Training and Development Institute (CFTDI) Trinidad and Tobago. 27 p.

Karim, M. (2009). Produksi Kepiting Lunak Mata Pencaharian Alternatif. Staf Pengajar Fakultas. Ilmu Kelautan dan Perikanan UNHAS.

Keenan C. P. (1999). The Fourth Species of Scylla. Di dalam: Keenan C.P and A. Blackshaw, editor. Mud Crab Aquaculture and Biology. 1997 April 21 -24. Darwin, Australia. Brisbane, Australia: PK Editorial Services, p48.

Manohas, J., Prayitno, M. R. E., dan Purwanto, Y. (2012). Perbandingan Hasil Tangkapan Kepiting dengan Menggunakan tiga konstruksi bubu kepiting yang berbeda di Desa Minanga, Kecamatan Bantauna, Bolaang Mongondow Utara. Jurnal Matric Edisi 1,No. 17 Juni, Tahun 2012. (Diakses tanggal, 18 Pebruari 2013)

Matsuura K., Sumadhiharga, O. K., \& Tsukomoto. (2000). Field Guide to Lombok Island. identification guide to marine organism in Seagrass Beds of Lombok Island, Indonesia. Ocean Research Institute, University of Tokyo, p449.

Muchlisin, Z. A., \& dan Azwir (2004). Hasil tangkapan kepiting bakau (Scylla serrata) 


\section{Macrothink}

Journal of Environment and Ecology

ISSN 2157-6092

2014, Vol. 5, No. 1

dengan menggunakan beberapa jenis umpan. Jurnal Ilmiah MIPA Vol. VII, No. 1, April 2004. (Diakses tanggal, 18 Pebruari 2013).

Odum, E. P. (1971). Fundamental ecology. W.B Sounder, Co, Philadelphia, p574.

Risamasu F. J. L. (2008). Inovasi teknologi penangkapan ikan karang dengan bubu dasar berumpon [disertasi]. Bogor: Program Pascasarjana, Institut Pertanian Bogor. 244 halaman.

Risamasu, F. J. L., Tjendanawangi, A., Liufetoa, F. Ch., Ninef, J. S. R., \& dan Jasmanindar, J. (2011). Kajian potensi sumberdaya ikan dan non ikan sebagai sumber pangan di Kabupaten Kupang. Laporan penelitian. 